\title{
ANALISIS PENGARUH TINGGI HAK SEPATU TERHADAP NYERI KAKI PADA PRAMUNIAGA KOSMETIK DI MANADO
}

\author{
${ }^{1}$ Christiana Ruri Sinta \\ ${ }^{2}$ Jimmy F. Rumampuk \\ ${ }^{2}$ Fransiska Lintong
}

\author{
${ }^{1}$ Kandidat Skripsi Fakultas Kedokteran Universitas Sam Ratulangi Manado \\ ${ }^{2}$ Bagian Fisika Fakultas Kedokteran Universitas Sam Ratulangi Manado \\ Email : christianarurisinta@yahoo.co.id
}

\begin{abstract}
The using of high heels can caused chronic defect and probability increase traumatic. The short period effect to the user of high heels especially for those who are rarely using them is medical infection of joint and foot swelling with foot pain in bone. This research purpose to know the connection of high of shoes heels and foot pain in bone. The method is analytic research by using cross sectional study approach, involve 30 subjects. It was done in november 2013 at megamall multimart, samrat multimart, golden and bahu freshmart. The data have got by interview and compare the pain scale, measuring the high of shoes heels and questionnaire. The research result indicated that the high of shoes heels average used by the cosmetic sales girls during her working are $5 \mathrm{~cm}(30 \%)$ and $7 \mathrm{~cm}(34 \%)$. and after measurements were taken and tested using a pain scale correlation test there is no significant difference in values $(\mathrm{P}>$ 0.05). From bivariant analysis using correlation test indicated that the result was not significant $(p=0,18)$. Conclusion : there is not significant relation between the high of shoes heels and the foot pain in bone.
\end{abstract}

Key words: the high heels , the foot pain in bone.

\begin{abstract}
Abstrak: Penggunaan sepatu hak tinggi dapat menyebabkan kerusakan kronis dan meningkatkan kemungkinan terjadi trauma. Efek jangka pendek bagi pengguna sepatu hak tinggi khusus bagi mereka yang jarang menggunakannya yaitu peradangan sendi dan pembengkakan kaki serta nyeri. Penelitian ini bertujuan untuk mengetahui hubungan tinggi hak sepatu dengan nyeri kaki. Metode penelitian yang digunakan yaitu penelitian analitik dengan menggunakan pendekatan studi potong lintang, sampel yang diambil 30 orang dan dilaksanakan pada bulan November 2013 di Multimart Megamall, Multimart Samrat, Golden dan Freshmart Bahu. .Data diperoleh dengan wawancara dan mencocokkan skala nyeri, pengukuran tinggi hak sepatu serta kuesioner. Hasil penelitian menunjukkan bahwa rata-rata tinggi hak sepatu yang digunakan pramuniaga kosmetika selama bekerja yaitu $5 \mathrm{~cm}$ (30\%) dan $7 \mathrm{~cm}$ (34\%) dan setelah dilakukan pengukuran skala nyeri dan diuji menggunakan uji korelasi tidak terdapat perbedaan nilai yang bermakna ( $\mathrm{p}>0.05$ ). Hal ini terlihat pada hasil uji korelasi antara tinggi hak sepatu dengan nyeri kaki setelah pemakaian sepatu hak tinggi $(\mathrm{p}=0.18)$. Simpulan: tinggi hak sepatu tidak berpengaruh pada nyeri kaki.
\end{abstract}

Kata kunci: nyeri kaki, sepatu hak tinggi.

Seiring kemajuan zaman, peran perempuan di dunia karier pun semakin besar. Aktivitas mereka semakin meningkat. Salah satu yang berperan dalam aktivitas seorang wanita adalah sepatu. ${ }^{1}$ Wanita yang menggunakan sepatu hak tinggi cenderung bertambah.
Para ahli mengkhawatirkan tentang kerusakan jangka panjang yang mereka lakukan pada tungkai dan badan. Rata-rata tinggi hak sepatu digunakan mulai dari 3-6 inchi. $^{2}$ Sepatu ber-hak tinggi beresiko mengakibatkan cedera akibat terjatuh, 
memperpendek otot betis, dan membuat cara berjalan pemakainya menjadi kurang nyaman atau canggung. ${ }^{1}$ Delapan dari sepuluh wanita mengakui bahwa pemakaian sepatu ber-hak tinggi menyebabkan nyeri di kaki mereka. ${ }^{2}$ Survei dari dua ratus wanita yang secara teratur menggunakan sepatu hak tinggi menemukan bahwa sekitar setengah dari mereka menderita nyeri dan merasa terbatas dalam kegiatan mereka setiap hari saat menggunakan hak antara 6-9 cm. ${ }^{3}$ Namun mereka terpaksa demi penampilan yang sempurna. Pada survei, 37 $\%$ wanita yang menjadi responden mengakui akan tetap memakai hak tinggi, sekalipun mereka merasa tidak nyaman. ${ }^{1}$ Kasus hukum mengenai perempuan yang dipaksa untuk memakai sepatu hak tinggi dalam lingkungan kerja dan mereka yang terkait telah banyak diungkap. ${ }^{4}$

Penggunaan sepatu hak tinggi dapat menyebabkan kerusakan kronis dan meningkatkan kemungkinan terjadi trauma. Efek jangka pendek bagi pengguna sepatu hak tinggi khusus bagi mereka yang jarang menggunakannya yaitu peradangan sendi dan pembengkakan kaki serta nyeri. Pada beberapa contoh, dapat pula terjadi fraktur dan patahan yang dapat dilihat secara mikroskopik. Sedangkan efek jangka panjang ialah kaku pada otot punggung dan tendon Achilles. Terdapat akibat untuk hal ini, yaitu fraktur pada telapak kaki.

Bila terjadi fraktur pada telapak kaki, ada kemungkinan terjadi osteoarthritis dan peradangan. ${ }^{5}$ Terdapat juga kemungkinan pembentukan hallux valgus. Hallux valgus adalah deformitas dari sendi metatarsofalangeal pada dasar kaki. Hallux valgus berkembang ketika tulang pertama metatarsal berubah arah keluar dan ibu jari masuk, yang menyebabkan sendi menonjol. Sepatu hak tinggi dapat memperburuk keadaan ini dengan mengubah penyokongan berat badan ke depan dan membelokkan jari ke depan sepatu. ${ }^{6}$

Perasaan tidak nyaman oleh pemakaian sepatu hak tinggi didominasi oleh nyeri kaki. Penyempitan arteri juga dapat menurunkan aliran darah ke tungkai yang berperan untuk nyeri. Nyeri setelah berdiri atau duduk, diakibatkan oleh penambahan cairan dalam vena tungkai yang terjadi ketika katup tidak bekerja saat menjaga darah berpindah dari tungkai ke jantung. Perpanjangan masa istirahat dan inaktivitas termasuk duduk atau berdiri dalam satu posisi untuk periode lama atau imobilisasi lama dari tungkai atau lengan seperti splint juga dapat meningkatkan resiko pembekuan darah. $^{7}$

\section{METODE PENELITIAN}

Penelitian ini merupakan penelitian analitik dengan menggunakan pendekatan studi potong lintang untuk mengetahui hubungan tinggi hak sepatu terhadap nyeri kaki pada pramuniaga kosmetik di Manado. Penelitian dilaksanakan di Multimart Megamall, Multimart Samrat, Golden, dan Freshmart Bahu pada bulan November 2013.

Populasi terjangkau penelitian ini adalah seluruh pramuniaga kosmetik yang bekerja pada di Multimart Megamall, Multimart Samrat, Golden, dan Freshmart Bahu. Peneliti mengambil sebagai sampel pramuniaga kosmetika sebanyak 30 orang dengan metode pengambilan consecutive sampel, dengan semua sampel yang datang dan memenuhi kriteria dijadikan sampel sampai jumlah sampel terpenuhi dan dalam posisi pelayan. ${ }^{8}$

Sampel yaitu semua pramuniaga kosmetik yang bekerja pada Multimart Megamall. Multimart Samrat, Golden, dan Freshmart Bahu yang memenuhi kriteria inklusi yakni wanita eabanyak 30 orang yang berusia maksimal 25 tahun, memakai sepatu hak tinggi dengan tinggi sepatu 5-10 $\mathrm{cm}$, bekerja dengan posisi berdiri minimal 6 jam per hari serta subyek bersedia berpartisipasi.

\section{HASIL}

Distribusi data berdasarkan karakteristik subyek penelitian dan faktor resiko. 
Sinta, Rumampuk, Lintong; Analisis Pengaruh Tinggi Hak Sepatu...

Distribusi data berdasarkan karakteristik subjek penelitian

Karakteristik subjek penelitian dalam penelitian ini meliputi umur, tinggi hak sepatu, dan skala nyeri.

\section{Umur}

Distribusi data berdasarkan kelompok umur responden yaitu, 20-21 tahun, 22-23 tahun, dan 24-25 tahun. Diperoleh data kelompok umur 20-21 tahun sebanyak 3 orang (9\%), diikuti kelompok umur 22-23 tahun sebanyak 14 orang (47\%), dan kelompok umur 24-25 tahun sebanyak 13 orang (43\%).Distribusi jumlah data menurut umur pada responden dapat dilihat pada Tabel 1.

Tabel 1. Distribusi data berdasarkan umur pada responden kuesioner di Manado

\begin{tabular}{ccc}
\hline Umur & Jumlah & Persentase (\%) \\
\hline 20-21 tahun & 3 & $10 \%$ \\
22-23 tahun & 14 & $47 \%$ \\
24-25 tahun & 13 & $43 \%$ \\
Total & 30 & $100 \%$ \\
\hline
\end{tabular}

\section{Tinggi hak sepatu}

Distribusi data menurut tinggi hak sepatu dikelompokkan menurut panjang hak sepatu yaitu $5 \mathrm{~cm}, 6 \mathrm{~cm}, 6.5 \mathrm{~cm}, 7 \mathrm{~cm}, 7.5$ $\mathrm{cm}, 8 \mathrm{~cm}, 9 \mathrm{~cm}$, dan $10 \mathrm{~cm}$. Diperoleh data pada tinggi hak sepatu $5 \mathrm{~cm}$ sebanyak 9 orang (30\%), diikuti tinggi hak sepatu $6 \mathrm{~cm}$ sebanyak 1 orang (3\%), tinggi hak sepatu $6.5 \mathrm{~cm}$ sebanyak 1 orang (3\%), tinggi hak sepatu $7 \mathrm{~cm}$ sebanyak 10 orang (34\%), tinggi hak sepatu $8 \mathrm{~cm}$ sebanyak 3 orang (10\%), tinggi hak sepatu $9 \mathrm{~cm}$ sebanyak 3 orang (10\%), dan tinggi hak sepatu $10 \mathrm{~cm}$ sebanyak 1 orang (3\%).

\section{Skala nyeri}

Distribusi data menurut skala nyeri Bourbonnais dari hasil kuesioner pada responden dikelompokkan menurut skala nyeri yaitu 0 atau tidak nyeri, $1-3$ pada nyeri ringan, 4-6 atau nyeri sedang, 7-9 atau nyeri berat terkontrol, dan 10 pada nyeri berat tidak terkontrol. ${ }^{9}$ Diperoleh data pada skala 0 atau tidak nyeri sebanyak 1 orang (3\%), diikuti skala 1-3 pada nyeri ringan sebanyak 7 orang (23\%), skala 4-6 pada nyeri sedang sebanyak 18 orang (60\%), skala nyeri 7-9 pada nyeri berat terkontrol sebanyak 4 orang (14\%).

Tabel 2. Distribusi data berdasarkan tinggi hak sepatu pada responden kuesioner di Manado

\begin{tabular}{ccc}
\hline Hak & Jumlah & Persentase (\%) \\
\hline $5 \mathrm{~cm}$ & 9 & $30 \%$ \\
$6 \mathrm{~cm}$ & 1 & $3 \%$ \\
$6.5 \mathrm{~cm}$ & 1 & $3 \%$ \\
$7 \mathrm{~cm}$ & 10 & $34 \%$ \\
$7.5 \mathrm{~cm}$ & 2 & $7 \%$ \\
$8 \mathrm{~cm}$ & 3 & $10 \%$ \\
$9 \mathrm{~cm}$ & 3 & $10 \%$ \\
$10 \mathrm{~cm}$ & 1 & $3 \%$ \\
Total & 30 & $100 \%$ \\
\hline
\end{tabular}

Tabel 3. Distribusi data berdasarkan skala nyeri pada responden kuesioner di Manado

\begin{tabular}{cccc}
\hline $\begin{array}{c}\text { Ang- } \\
\text { ka }\end{array}$ & Skala Nyeri & $\begin{array}{c}\text { Jum- } \\
\text { lah }\end{array}$ & $\begin{array}{c}\text { Persentase } \\
(\mathbf{\%})\end{array}$ \\
\hline 0 & tidak nyeri & 1 & $3 \%$ \\
$1-3$ & nyeri ringan & 7 & $23 \%$ \\
$4-6$ & nyeri sedang & 18 & $60 \%$ \\
$7-9$ & nyeri berat & 4 & $14 \%$ \\
& terkontrol & 30 & $100 \%$ \\
\hline
\end{tabular}

\section{Karakteristik Faktor Resiko}

Karakteristik faktor resiko pada penelitian ini yaitu jam kerja, frekuensi penggunaan sepatu hak tinggi dan lama pemakaian sepatu hak tinggi dengan hasil sebagai berikut:

\section{Jam Kerja}

Distribusi data berdasarkan jam kerja dikelompokkan berdasarkan jam, yaitu $\leq 6$ jam, 6-8 jam, dan $\geq 8$ jam. Diperoleh data pada 6-8 jam kerja sebanyak 28 orang (93\%) dan pada jam kerja yang lebih dari 8 jam sebanyak 2 orang (7\%). 
Tabel 4. Distribusi data berdasarkan jam kerja pada responden kuesioner di Manado

\begin{tabular}{ccc}
\hline Jam Kerja & Jumlah & Persentase (\%) \\
\hline 6 - 8 jam & 28 & $93 \%$ \\
$\geq 8$ jam & 2 & $7 \%$ \\
Total & 30 & $100 \%$ \\
\hline
\end{tabular}

\section{Frekuensi penggunaan sepatu hak tinggi}

Distribusi data berdasarkan frekuensi penggunaan sepatu hak tinggi dikelompokkan sebagai berikut, yaitu $\leq 3 \mathrm{x}$ dalam seminggu, 4-6 kali dalam seminggu, dan $>6$ kali dalam seminggu. Didapatkan data pada frekuensi 4-6 kali dalam seminggu sebanyak 27 orang (90\%) dan pada frekuensi $>6$ kali dalam seminggu sebanyak 3 orang (10\%).

Tabel 5. Distribusi data berdasarkan frekuensi penggunaan sepatu hak tinggi pada responden kuesioner di Manado

\begin{tabular}{ccc}
\hline Frekuensi & Jumlah & Persentase (\%) \\
\hline $4-6$ kali & 27 & $90 \%$ \\
$>6$ kali & 3 & $10 \%$ \\
Total & 30 & $100 \%$ \\
\hline
\end{tabular}

\section{Lama pemakaian sepatu hak tinggi}

Distribusi data berdasarkan lama pemakaian sepatu hak tinggi dikelompokkan sebagai berikut yaitu pada $<1$ tahun pemakaian,2-3 pemakaian dan $>3$ tahun pemakaian. Didapatkan data pada $<1$ tahun pemakaian sebanyak 2 orang (7\%), diikuti 2-3 tahun pemakaian sebanyak 6 orang (20\%), dan >3 tahun pemakaian sebanyak 22 orang (73\%).

Analisa bivariat dilakukan untuk dapat mengetahui hubungan antara tinggi hak sepatu dengan nyeri kaki. Analisis digunakan dengan menggunakan analisis Uji Korelasi. Hasil dari analisis uji ini didapatkan bahwa tinggi hak sepatu dengan nilai $\mathrm{p}=0.18$.
Tabel 6. Distribusi data berdasarkan lama pemakaian sepatu hak tinggi pada responden kuesioner di Manado

\begin{tabular}{ccc}
\hline Lama Pemakaian & Jumlah & Persentase (\%) \\
\hline$<1$ tahun & 2 & $7 \%$ \\
2 - 3 tahun & 6 & $20 \%$ \\
$>3$ tahun & 22 & $73 \%$ \\
Total & 30 & $100 \%$ \\
\hline
\end{tabular}

Tabel 7. Hasil Analisa Bivariat Uji Korelasi

\begin{tabular}{ccc}
\hline & $\begin{array}{c}\text { Nilai } \boldsymbol{p} \\
\text { value }\end{array}$ & Hasil Analisis \\
\hline $\begin{array}{c}\text { Tinggi Hak } \\
\text { Sepatu }\end{array}$ & 0.18 & $\begin{array}{c}\text { Tidak } \\
\text { Signifikan }\end{array}$ \\
Standar & 0.05 & \\
\hline
\end{tabular}

\section{BAHASAN}

\section{Karakteristik subjek penelitian}

Setelah dilakukan pengolahan data diperoleh data menurut usia pada kelompok umur 20-21 tahun sebanyak 3 orang (9\%), diikuti kelompok umur 22-23 tahun sebanyak 14 orang (47\%), dan kelompok umur 24-25 tahun sebanyak 13 orang (44\%). Distribusi data selanjutnya diperoleh berdasarkan tinggi hak sepatu responden, yaitu tinggi hak sepatu $5 \mathrm{~cm}$ sebanyak 9 orang (30\%), diikuti tinggi hak sepatu $6 \mathrm{~cm}$ sebanyak 1 orang (3\%), tinggi hak sepatu $6.5 \mathrm{~cm}$ sebanyak 1 orang (3\%), tinggi hak sepatu $7 \mathrm{~cm}$ sebanyak 10 orang (34\%), tinggi hak sepatu $8 \mathrm{~cm}$ sebanyak 3 orang (10\%), tinggi hak sepatu $9 \mathrm{~cm}$ sebanyak 3 orang (10\%), dan tinggi hak sepatu $10 \mathrm{~cm}$ sebanyak 1 orang (3\%).

Distribusi data berdasarkan skala nyeri dari hasil kuesioner pada responden, didapatkan pada skala 0 atau tidak nyeri sebanyak 1 orang (3\%), diikuti skala $1-3$ pada nyeri ringan sebanyak 7 orang (23\%), skala 4-6 pada nyeri sedang sebanyak 18 orang (60\%), skala nyeri 7-9 pada nyeri berat terkontrol sebanyak 4 orang (14\%). Kemudian distribusi data dikelompokkan berdasarkan factor resiko yaitu jamkerja, frekuensi penggunaan sepatu hak tinggi, 
lama pemakaian. Distribusi data berdasarkan jam kerja didapatkan pada 6-8 jam kerja sebanyak 28 orang (93\%) dan pada jam kerja $\geq 8$ jam sebanyak 2 orang (7\%). Distribusi data berdarakan frekuensi penggunaan sepatu hak tinggi didapatkan data pada frekuensi 4-6 kali dalam seminggu sebanyak 27 orang (90\%) dan pada frekuensi $>6$ kali dalam seminggu sebanyak 3 orang (10\%). Distribusi data berdasarkan lama penggunaan sepatu hak tinggi didapatkan data pada $<1$ tahun pemakaian sebanyak 2 orang (7\%), diikuti 2-3 tahun pemakaian sebanyak 6 orang (20\%), dan $>3$ tahun pemakaian sebanyak 22 orang (73\%).

\section{Analisa tinggi hak sepatu terhadap nyeri kaki}

Berdasarkan hasil penelitian dengan melakukan pengukuran tinggi hak sepatu dan pengisian kuesioner untuk melihat skala nyeri pada responden, didapatkan bahwa 60 $\%$ dari responden mengeluh mengalami nyeri sedang. Dimana nyeri sedang yaitu subjek penelitian responsive terhadap tindakan manual, dapat menunjukkan lokasi nyeri dan dapat mengikuti perintah. ${ }^{9}$

Sesuai dengan penemuan Isaac Newton bahwa bilamana suatu benda A memberi gaya $F$ pada suatu benda $B$, pada waktu bersamaan benda $\mathrm{B}$ memberi gaya $\mathrm{R}$ pada benda $\mathrm{A}$; gaya $\mathrm{R}$ sama dengan gaya $\mathrm{F}$ tetapi mempunyai arah yang berlawanan. ${ }^{10}$ Menurut Hukum Tekanan zat padat, dijelaskan bahwa wanita yang menggunakan sepatu hak tinggi, berat badan bertumpu pada permukaan sepatu yang terkena lantai. Sepatu hak tinggi saat ini mempunyai hak dengan luas hak 0,0625 cm ,luas permukaan tekanan yang akan diaplikasikan pada lantai sebesar $16 \mathrm{in}^{2}$. Sangat kontras dengan permukaan kaki gajah yang memiliki luas daerah tekanan sebesar 40 in $^{2}$ sehingga tekanan yang diberi oleh kaki gajah pada permukaan lebih kecil dibandingkan dengan tekanan yang diberikan oleh sepatu hak tinggi. Sedangkan bila menggunakan sepatu datar,tekanan yang diberi akan bertumpu pada permukaan sepatu yang terkena lantai (lebih lebar ) sehingga tekanannya menjadi lebih kecil. ${ }^{11}$ Hukum Newton yang ketiga menjelaskan bahwa untuk setiap reaksi ada hasil dan reaksi yang berlawanan. Ini berlaku untuk gaya yang diberikan pada lantai melalui sepatu hak tinggi yang menghasilkan reaksi dan berlawanan dengan gaya gravitasi. ${ }^{12}$ Reaksi pada lantai yang melawan gravitasi dengan memberikan tekanan yang lebih besar pada luas permukaan yang kecil ini yang berpengaruh pada kapiler darah yang tersumbat sehingga mengakibatkan penumpukan darah sampai kebocoran katup sehingga terjadilah nyeri. ${ }^{13}$

Akan tetapi pada analisa yang dilakukan antara tinggi hak sepatu dengan nyeri kaki tidak terdapat hubungan yang signifikan sebagaimana yang dapat dilihat pada table $4.7 \quad(\mathrm{p}=0.18, \mathrm{p}>0.05)$ walaupun pada hasilnya didapatkan nyeri akibat penggunaan sepatu hak tinggi. Hal ini mungkin dikarenakan kebiasaan dari sampel sendiri yang telah menggunakan sepatu hak tinggi $>3$ tahun sehingga nyeri yang dirasakan sudah berkurang, berbeda dengan mereka yang baru saja menggunakan sepatu hak tinggi dalam bekerja, dimana tubuh masih melakukan penyesuaian antara posisi tubuh dalam bekerja, berjalan dan berdiri selama bekerja menggunakan sepatu hak tinggi.

\section{SIMPULAN}

Berdasarkan hasil penelitian dan pembahasan dapat disimpulkan bahwa sebagian besar pramuniaga kosmetik menggunakan sepatu hak tinggi dengan tinggi $5 \mathrm{~cm}$ dan $7 \mathrm{~cm}$, serta penggunaan sepatu hak tinggi dengan berbagai variasi pada tinggi haknya tidak berpengaruh pada nyeri kaki yang terjadi pada pramuniaga kosmetik.

\section{KETERBATASAN PENELITIAN}

Penelitian ini memerlukan subyek lebih daripada 30 orang untuk mendapatkan variasi data. Selain itu perlu diperhatikan bahwa dalam penelitian ini lebih banyak subjek yang telah menggunakan sepatu hak tinggi lebih dari 3 tahun, oleh sebab itu nyeri yang dirasakan sudah tidak signifikan seperti pada mereka yang baru 
menggunakan sepatu hak tinggi. Pada penelitian ini juga terbatas pada model sepatu hak tinggi stiletto tanpa menyeleksi merk sepatu yang digunakan.

\section{SARAN}

Perlu diadakan penelitian lebih lanjut dengan berbagai macam sepatu hak tinggi untuk membandingkan nyeri yang didapatkan dan seleksi merk sepatu untuk melihat kenyamanan pemakainya, agar didapatkan hubungan nyeri yang lebih signifikan.

\section{UCAPAN TERIMA KASIH}

Ucapan terima kasih disampaikan kepada Prof. dr. Vennetia R. Danes, M.Sc, Ph.D (penguji I) dr. Wenny Supit, M.Repro, Sp. And (penguji II) dan kepada semua pihak yang telah memberi masukan dan gagasan kepada penulis dalam penulisan secara langsung dan tidak langsung sehingga artikel ini dapat terselesaikan.

\section{DAFTAR PUSTAKA}

1. Kesehatan. 7 Sepetember 2003. [11 September 2013]. Avaible from : http://nostalgia.tabloidnova.com/articles.asp ?id=2079

2. L.N. Michael. 23 February 2012. [14 September 2013]. Available from : http://nsthealth.wordpress.com/2012/02/23/h igh-heels-and-pain-how-to-prevent-it/

3. Lee C-M, Jeong E-H, Freivalds A: Biomechanical effects of wearing highheeled shoes. Int J Ind Ergon 2001, 28:321326.
4. Linder M: Smart Women, Stupid Shoes, and Cynical Employers: The Unlawfulness and Adverse Health Consequences of Sexually Discriminatory Workplace Footwear Requirements for Female Employees. $J$ Corp Law 1997, 22:295-329.

5. Morris HP, White J, Morrison ER, Fisher. High heels as supernormal stimuli: How wearing high heels affects judgements of female attractiveness. Evolution and Human Behavior. 2013; 34: 176-181

6. Harvard Medical School. What to do about bunions. June 2011. [26 January 2014]. Available from http://www.health.harvard.edu/newsletters/H arvard_Womens_Health_Watch/2011/June/ what-to-do-about-bunions

7. Kraitzer L. The effects of high heels. In : Koerting K, Melton K. Healthy You. $10^{\text {th }}$ ed. New York: Syracuse University College of Human Ecology and the Divisions of Undergraduate Studies and Student Affairs; 2010. $12-13$

8. Sastroasmoro S. Dasar-dasar Metodologi Penelitian Klinis. Edisi ke -4. Jakarta; Sagung Seto; 2011. 499

9. Astuti D.W. Ambar. Efektivitas Ekstrak Jahe Merah (Zingiber offidinale roscoe van Rubrum) Dalam Mengurangi Nyeri Otot pada Atlet Sepak Takraw. [Artikel Penelitian]. [Semarang]; UNDIP, 2011

10. Gabriel JF. Fisika Kedokteran. Edisi 7. Jakarta; EGC; 1996. 6

11. Berebichez D. The physics of heeled shoes. (or, "Using Newton's Laws to determine sole pressure.”). 2012.[8 Oktober 2013]. Available from : www.thegaitguys.com

12. Brown GR, Burns T. Lecture Notes : Dermatology. $8^{\text {th }}$ Ed. Jakarta: EMS; 2005. 184

13. Fisiologi Kedokteran. Edisi 1. Jakarta; Karisma Publishing. 2006. 149 